Original Research Paper

\title{
Development and Implementation of the HACCP System on the Production Line of Kefir from Goat's Milk
}

\author{
${ }^{1}$ Gaukhar Yussupova, ${ }^{1}$ Dina Kurmangaliyeva, ${ }^{3}$ Zhazira Shadyarova, \\ ${ }^{1}$ Begjan Kalemshariv, ${ }^{2}$ Nadezhda Lantseva, ${ }^{1}$ Askar Muratov and ${ }^{3}$ Zhadyra Salykbaeva \\ ${ }^{1}$ Kazakh Agrotechnical University Named After S. Seifullin, Nur-Sultan, Kazakhstan \\ ${ }^{2}$ Novosibirsk State Agrarian University, Novosibirsk, Russia \\ ${ }^{3}$ Atyrau State University Named After Kh. Dosmukhamedov, Atyrau, Kazakhstan
}

\author{
Article history \\ Received: 14-08-2020 \\ Revised: 03-10-2020 \\ Accepted: 09-10-2020 \\ Corresponding Author: \\ Gaukhar Yussupova \\ Kazakh Agrotechnical \\ University Named After S. \\ Seifullin, Nur-Sultan, \\ Kazakhstan \\ Email: gaukhar.yussupova@bk.ru
}

\begin{abstract}
The purpose of this work is to develop a HACCP plan with the subsequent implementation of the HACCP system to ensure the safety of production of kefir from goat's milk produced in the "Breeding farm" Zerenda "LLP in the Akmola region. When implementing HACCP defined policy and security of products, the scope of the HACCP system, the appointment of working group HACCP, identified hazards, identified Critical Control Points (CCP) for certain operations of the process and developed the cautionary measures to eliminate risks or reduce them to an acceptable level and the proposed corrective actions. Stages of hazard analysis are the basis of the HACCP system. The first stage of this analysis is to identify threats to human health and assess the identified hazard. Hazards are usually divided into three categories: Biological, chemical and physical. The second stage is the selection of critical control points. To select critical control points on the line for the production of kefir from goat's milk produced in LLP" Breeding farm "Zerenda" of Akmola region, the method of "Decision Tree" was used, which allows to determine critical control points at the stage of the technological process. The implementation of "Decision Tree" method proves that the stages of raw milk storage, pasteurization and fermentation, are critical control points in relation to the identified preliminary threats to the safety of the dairy product - kefir from goat's milk produced in "Breeding farm" Zerenda "LLP.
\end{abstract}

Keywords: Kefir From Goat's Milk, Quality, Safety, HACCP, Indicators, Dangerous Factors, Critical Control Points, Process Analysis

\section{Introduction}

In the last 10 years, the number of cows in Kazakhstan has been decreasing, while the productivity of the herd is not growing fast enough, so as a result, the gross milk production in the country is reduced. Milk production is decreasing, while consumption of dairy products, on the contrary, is increasing. One of the ways to solve the problem is to introduce milk from other animals, including goats, into the dairy industry. One of the most popular processed products from goat's milk is goat kefir. Kefir from goat's milk is a balanced product that has a high health value and has easy digestibility due to the fact that its fat balls and casein micelles are 10 times smaller than cow's milk, thus they are more easily absorbed by the intestinal walls and easily absorbed by the stomach. The presence of bifidobacteria in yogurt allows us to classify it as a so-called "live" food.

Kefir is a fermented milk product with a high content of dry skimmed milk substances, made using a mixture of fermenting microorganisms of thermophilic lactic acid streptococci and Bulgarian Bacillus, while the total content of fermenting microorganisms in the finished product at the end of the shelf life is at least $10^{7} \mathrm{CFU}$ per $1 \mathrm{~g}$ of the product.

High-quality kefir made from goat's milk is not easy to buy today. Only a product that contains live lactic acid bacteria - bifid bacteria - is useful for health. Their life span does not exceed 4-5 days. On the shelves of stores are mostly found kefir with a two-week or even a month shelf life. Naturally, this product does not 
contain any living bacteria. In this regard, we have developed kefir from goat's milk.

Currently, many countries recognize the problem of quality and safety of food products as one of their priority areas of activity. Cases of outbreaks of diseases associated with the consumption of low-quality food products indicate the need for a radical change in approaches to product quality in order to ensure food safety, reduce the risks of infection with diseases associated with the consumption of such products (Klementieva and Lanceva, 2017; Kantere et al., 2008).

Today, it is impossible to supply goods to the world market without knowledge of international standards. The principles of Hazard Analysis and Critical Control Points (HACCP), which are synonymous with safety for consumers in many countries, are widely recognized around the world (Vasileva, 2013; Baryshnikova et al., 2017; Bondareva, 2010).

In order to ensure that food safety meets the requirements of TR CU 021/2011, each company is required to develop, implement and maintain procedures based on the principles of HACCP in the implementation of food production (manufacturing) processes (Smirnova et al., 2015; Zamyamina, 2006).

HACCP is an integrated food safety control system, the implementation of which gives consumers confidence in the safety of production, allows them to strictly comply with the requirements of legislation in the field of food safety and demonstrate effective management of food safety in documents-evidence that can be used in the event of a lawsuit (Antonov and Shiryaev, 2015; Grevtsova et al., 2016).

The introduction of the HACCP system means that the company's management shifts its focus from General inspection of already manufactured products to conducting preventive control of possible hazards that may occur at any stage of the production cycle. In addition, HACCP contains practical recommendations on the means and methods of quality control (Tolstova, 2013; Mortimore, 2014; Aptrakhimov and Rebezov, 2014).

Advantages of implementing the HACCP system:

- Increasing consumer confidence in products, which in turn affects the company's sales and profits

- The HACCP system allows the manufacturer to specify documents and records confirming that food production is under control. This increases the level of customer and consumer confidence in the product itself

- New market access opportunities. There is growing market demand for safe products. Many wholesale buyers and retail chains require confirmation of food safety not only by certificates of safety of the product itself, but also by certificates of safe production. The existing HACCP system provides opportunities and offers (Yussupova et al., 2019; Prokoshenkova and Lantseva, 2019)
The purpose of this work is to develop a HACCP plan with the subsequent implementation of the HACCP system to ensure the safety of production of kefir from goat's milk produced in the "Breeding farm "Zerenda "LLP in the Akmola region.

\section{Materials and Methods}

The subject of research is the process of production of dairy products- kefir from goat's milk produced in the "Breeding farm "Zerenda "LLP of Akmola region. The development of the HACCP plan was carried out according to the standard of ST RK ISO 22000-2006" Food safety management systems - requirements for any organization in the food chain" and ST RK 1179-2003" Quality systems. HACCP principles for food products quality management. General requirements". When implementing the HACCP system, the following sequence of actions was carried out: Creating a policy; determining the safety area of products and the distribution area of the HACCP system at the enterprise; appointing a working group for the development and implementation of HACCP; determining hazards; identifying critical control points and their permissible limits; developing documentation for preventive and corrective actions.

\section{Results and Discussion}

The first priority when applying HACCP at a milk processing plant was to create a team with the knowledge and experience to develop an HACCP plan. The formed team was multidisciplinary and included employees of the company from the Department of production, sanitation and quality assurance, in accordance with the requirements of the Standard (ST RK ISO 22000-2006; ST RK 1179-2003) personal responsibility for the safety of dairy products - kefir from goat's milk, is assigned to the head of the company. The object of research is the area of distribution of the HACCP system - a technological line for the production of kefir from goat's milk, including the following stages: Acceptance of raw milk, acceptance of fungal leaven, purification of raw milk, cooling and storage of raw milk, separation, normalization, purification, homogenization, pasteurization, cooling, fermentation of products, fermentation, mixing and cooling, maturation, bottling, packaging, labeling. A block diagram of the process of producing kefir from goat's milk is shown in Fig. 1. The source data for conducting threat analysis and developing an HACCP plan is the product description in the organization's standard (Table 1) the list of raw materials and ingredients used is given in Table 2.

Sourdough on kefir fungi is produced in accordance with the requirements of the "Technological instructions for the preparation and use of starter cultures and bacterial concentrates for fermented milk products in the dairy industry". 


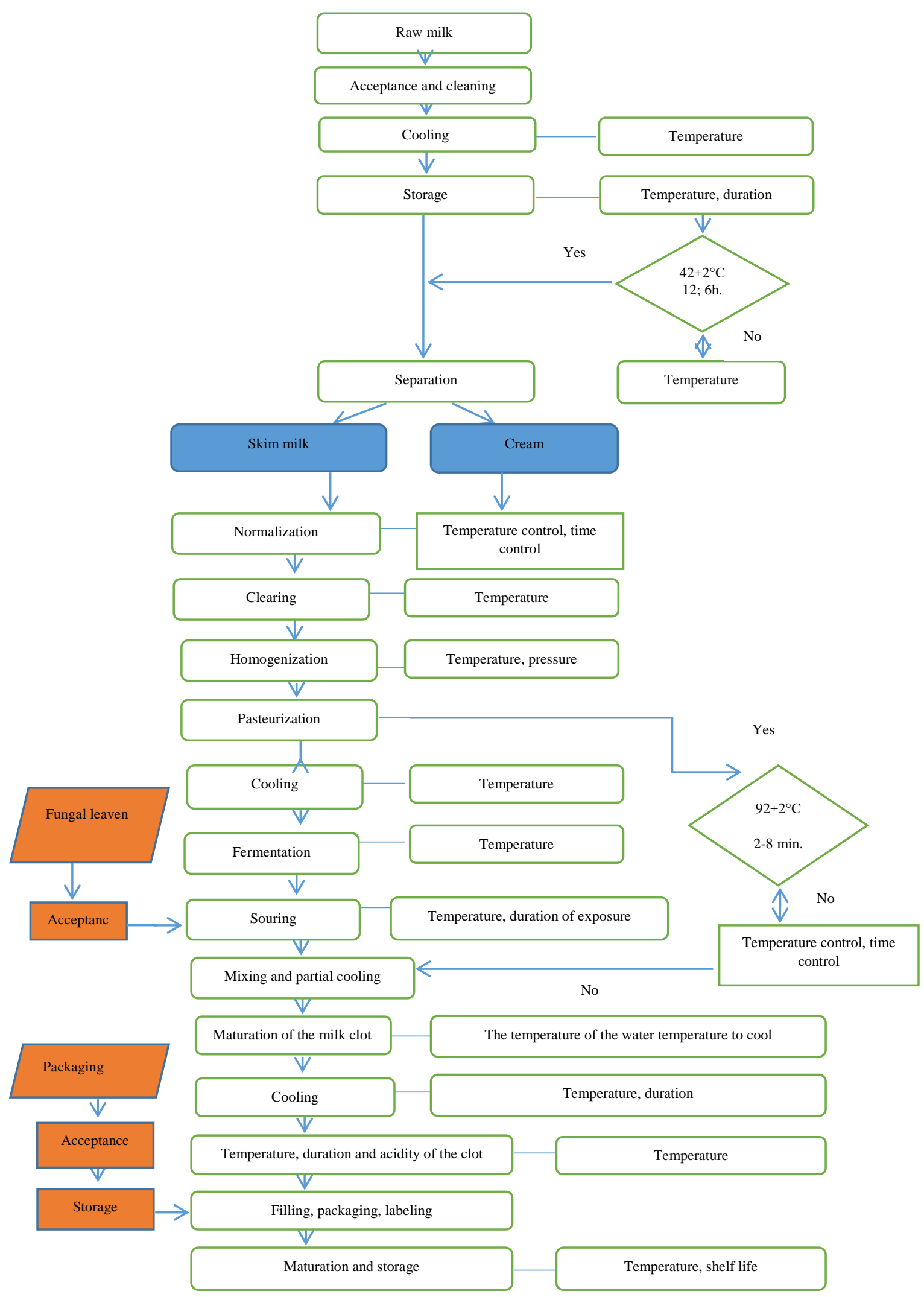

Fig. 1: Block diagram of production of products - kefir from goat's milk 


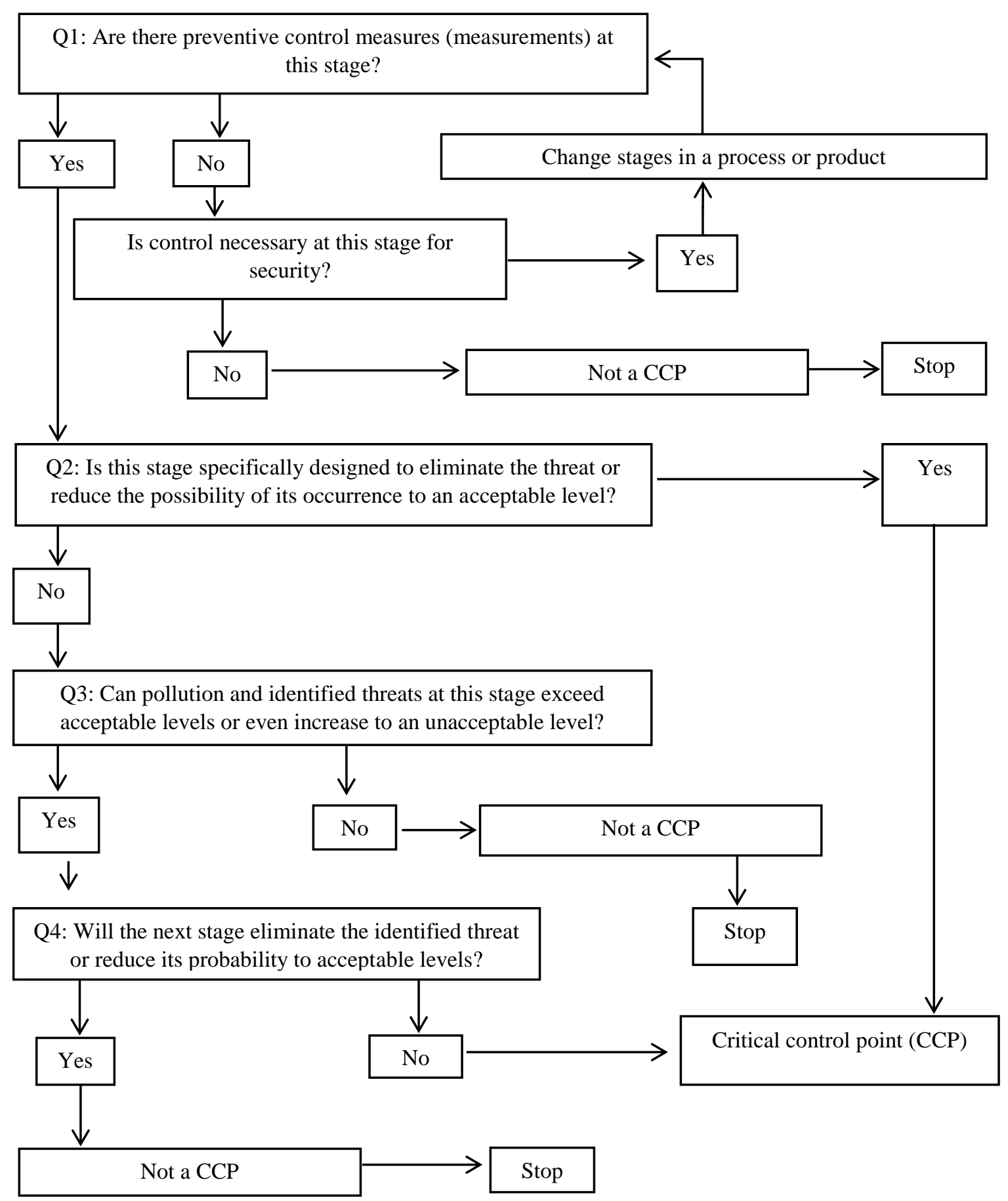

Fig. 2: Determination of critical control points for the "Decision Tree" on the production line of kefir from goat's milk

Further, after determining the product requirements, we analyzed various types of hazards, the possibility of changing the stages of the technological process, the operation of equipment and the threat of new risks. This stage allows you to identify all potential risks at different stages of the product life cycle. Risk analysis is carried out in two stages: Risk identification and risk assessment. At these stages, it is necessary to consider all possible types of potentially dangerous factors: Microbiological, chemical and physical, which can affect the safety of the finished product during the technological process.

After the risks and appropriate procedures for their control were identified in the production of products kefir from goat's milk, we were assigned and completed the task of assessing each risk in terms of the severity of consequences and the likelihood of its implementation. 
Table 1: Description of the product - kefir from goat's milk

\begin{tabular}{|c|c|}
\hline Product & Kefir from goat's milk standard of organization 140540024607-03-2018 \\
\hline $\begin{array}{l}\text { Product characteristics that are } \\
\text { important for its safety }\end{array}$ & $\begin{array}{l}\text { Acidity }-85 \text { to } 130 \mathrm{t}^{0} \text {; clean taste and smell, sour-milk, salty taste, without foreign tastes and odors; } \\
\text { consistency is homogeneous, gas formation is allowed; weight fat percentage of } 2.5 \% \text {. }\end{array}$ \\
\hline How it will be used & Ready for use \\
\hline Prospective consumers & All population groups, including children, the elderly and the sick \\
\hline Packaging & Containers made of polymer material with a capacity of 0,51 to 11 \\
\hline Shelf life & 10 days at a temperature of $4 \pm 2^{\circ} \mathrm{C}$ \\
\hline Place of implementation & Retail stores, preschool and school institutions, medical and Spa institutions \\
\hline Instructions on the label & Store at a temperature of $4 \pm 2^{\circ} \mathrm{C}$ until (specific shelf life) \\
\hline Terms of delivery & Refrigerated by special means of transport \\
\hline
\end{tabular}

Table 2: List of raw materials and ingredients used for the production of products-kefir from goat's milk

\begin{tabular}{ll}
\hline Indicator & Components \\
\hline Dairy ingredients & Raw goat milk according to GOST 32940-2014 The yeast in kefir fungi \\
Other ingredient & -
\end{tabular}

Table 3: Identification of hazards and preventive actions on the production line of kefir from goat's milk

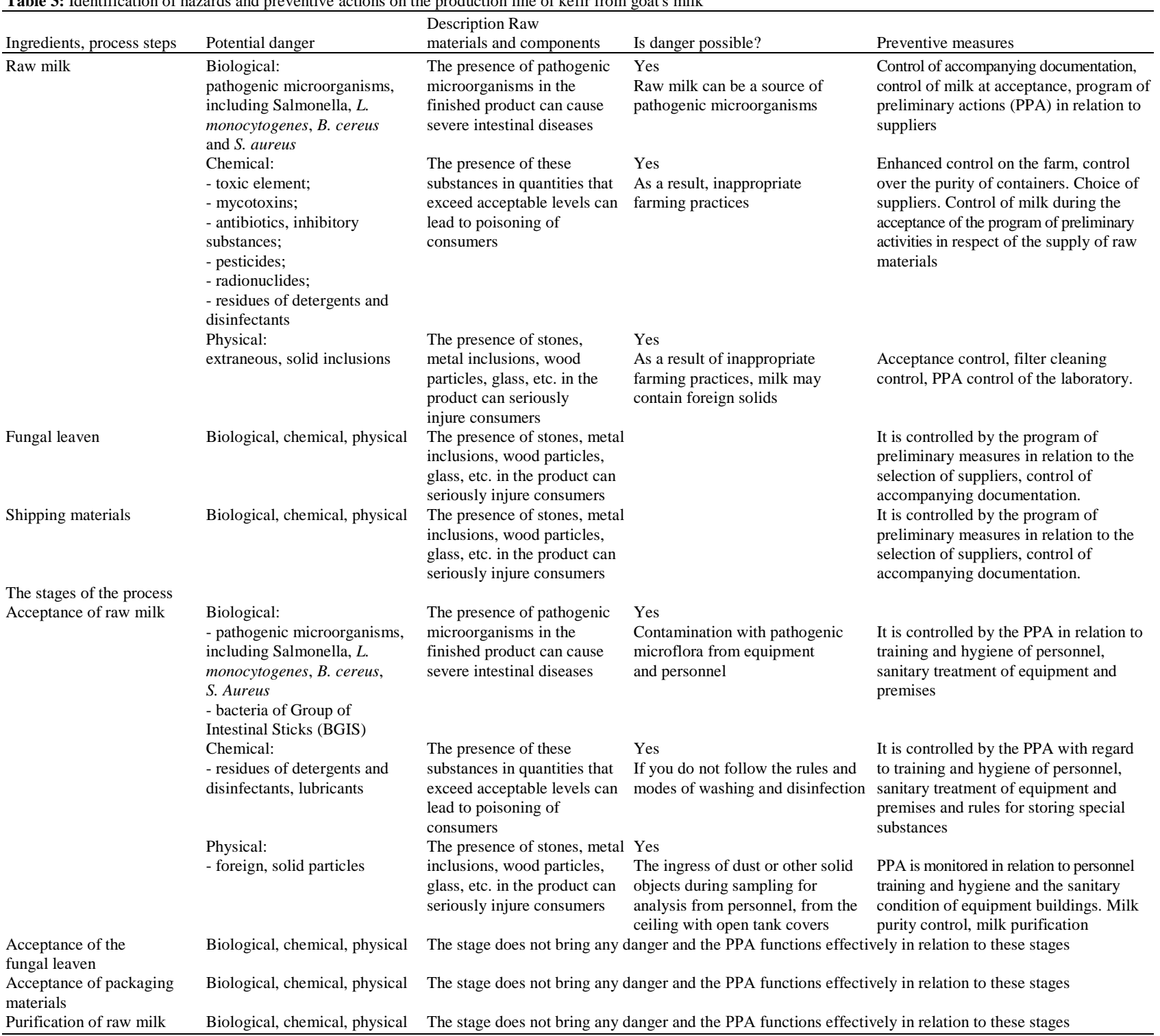


Table 3: Continue

$\begin{array}{ll}\text { Cooling and storage of raw } & \text { Biological: } \\ \text { milk at a temperature of } & \text { - pathogenic microorganisms, } \\ 4 \pm 2^{\circ} \mathrm{C} & \text { including Salmonella, } L . \\ & \text { monocytogenes, B. cereus, } \\ & \text { S. Aureus } \\ & \text { - BGIS }\end{array}$

Chemical:

- enterotoxins;

- residues of detergents and

disinfectants, lubricants

Physical

Separation

Normalization

Clearing

Homogenization

Pasteurization

Fermentation

Souring

Biological

- pathogenic microorganisms,

including Salmonella, $L$.

monocytogenes, B. cereus,

S. Aureus

- BGIS

Chemical

Physical

Mixing and partial cooling Maturation of the milk clot Cooling

Pouring

Biological, chemical, physical

Biological, chemical, physical

Biological, chemical, physical

Biological:

- moulds

Chemical - residue of

detergents and disinfectants

Physical
The presence of pathogenic Yes

microorganisms in the When storing raw milk in an

finished product can cause uncooled state, pathogenic

severe intestinal diseases

microflora may grow to an

unacceptable level; contamination

from equipment, air and external

sources may occur

Enterotoxins in the finished Yes

product can lead to severe

intestinal diseases, up to a

fatal outcome. Detergent

residues can cause allergies

or lead to poisoning of

consumers

The stage does not bring any danger and the PPA functions effectively in relation to these stages

The stage does not bring any danger and the PPA functions effectively in relation to these stages

The stage does not bring physical danger in the presence of PPA

The stage does not bring physical danger in the presence of PPA

The stage does not bring physical danger in the presence of PPA

The development of Yes

pathogenic microorganisms The pathogenic microflora that

in the finished product can survived as a result of the

lead to severe intestinal violation of the regime can

diseases

manifest itself at the stage of

fermentation and in the finished product

Yes

Poisoning of consumers

If the washing and disinfection modes are not observed

The stage does not bring physical danger in the presence of PPA

The development of Yes

pathogenic microorganisms Secondary contamination from

in the finished product can non-pasteurized milk through

lead to severe intestinal small cracks

diseases

Poisoning of consumers

Yes

If the washing and disinfection

modes are not observed

The stage does not bring physical danger in the presence of PPA The development of Yes

pathogenic microorganisms When applying the starter,

in the finished product can contamination from personnel,

lead to severe intestinal the environment and equipment

diseases

is possible

Poisoning of consumers

Yes

If you do not follow the rules and PPA for washing and sanitizing modes of washing and disinfection equipment

The presence of stones, metal Yes

inclusions, wood particles, When making leaven from the glass, etc. in the product can staff, the environment seriously injure consumers.

The presence of pathogenic

microorganisms in the

Possible development of

pathogenic microflora as a result

severe intestinal diseases

of non-compliance with souring regimes

Enterotoxins in the finished As a result of non-compliance product can lead to severe with souring regimes, the product intestinal disease up to death. mathovelop patho enterotoxins that do not break down during heat treatment

The stage does not bring physical danger in the presence of PPA

The stage does not bring physical danger in the presence of PPA

The stage does not bring physical danger in the presence of PPA

The stage does not bring physical danger in the presence of PPA Mould can lead to product Yes

damage and poisoning Mould contamination from equipment, environment and packaging

Poisoning of consumers Yes

If you do not follow the rules and PPA for washing and sanitizing modes of washing and disinfection equipment

Control point. Compliance with PPA pasteurization regimes with regard to equipment serviceability

PPA in relation to washing and sanitizing equipment.

Monitoring and ensuring the pressure of pasteurized milk

PPA for cleaning and sanitizing equipment.

PPA for cleaning and sanitizing equipment and premises

PPA for cleaning and sanitizing equipment and premises

Control point. Maintaining the fermentation temperature no more than $22^{\circ} \mathrm{C}$ until pH 4.65-4.5 is reached. PPA for washing and sanitizing equipment

Control point. Maintaining the fermentation temperature no more than $22^{\circ} \mathrm{C}$ until pH 4.65-4.5 is reached. PPA for washing and sanitizing equipment

PPA in relation to the maintenance of equipment and premises, selection of suppliers of packaging materials, packaging control

The stage does not bring physical danger in the presence of PPA 


\begin{tabular}{|c|c|c|c|c|}
\hline \multirow[t]{3}{*}{ Packing } & $\begin{array}{l}\text { Biological: } \\
\text { - moulds }\end{array}$ & $\begin{array}{l}\text { Pathogenic microorganisms } \\
\text { in the finished product can } \\
\text { hardly develop, but mould } \\
\text { can lead to product damage } \\
\text { and poisoning }\end{array}$ & $\begin{array}{l}\text { Yes } \\
\text { Possible contamination from } \\
\text { personnel, equipment, environment } \\
\text { and packaging materials }\end{array}$ & $\begin{array}{l}\text { PPA in relation to staff hygiene, repair } \\
\text { and maintenance of training and premises, } \\
\text { selection of suppliers of packaging } \\
\text { materials, packaging control }\end{array}$ \\
\hline & $\begin{array}{l}\text { Chemical: } \\
\text { - residue of detergents and } \\
\text { disinfectants }\end{array}$ & Poisoning of consumers & $\begin{array}{l}\text { Yes } \\
\text { If you do not follow the rules and } \\
\text { modes of washing and disinfection }\end{array}$ & $\begin{array}{l}\text { PPA for washing and sanitizing } \\
\text { equipment }\end{array}$ \\
\hline & $\begin{array}{l}\text { Physical } \\
\text { - foreign solid particles, } \\
\text { fibers, etc. }\end{array}$ & $\begin{array}{l}\text { The presence of stones, metal } \\
\text { inclusions, wood particles, } \\
\text { glass, etc. in the product can } \\
\text { seriously injure consumers }\end{array}$ & $\begin{array}{l}\text { It is possible to get foreign } \\
\text { objects from the staff, from the } \\
\text { surrounding environment }\end{array}$ & $\begin{array}{l}\text { PPA in relation to staff hygiene, repair } \\
\text { and maintenance of training and } \\
\text { premises }\end{array}$ \\
\hline \multirow[t]{2}{*}{ Marking } & $\begin{array}{l}\text { Biological and chemical: } \\
\text { - products of microbiological } \\
\text { and chemical spoilage of the } \\
\text { product }\end{array}$ & $\begin{array}{l}\text { The presence of } \\
\text { microbiological and chemical } \\
\text { spoilage in products can lead } \\
\text { to severe poisoning }\end{array}$ & $\begin{array}{l}\text { If the production date is incorrectly } \\
\text { applied to the label, the product } \\
\text { may be available for consumption } \\
\text { after the expiration date }\end{array}$ & $\begin{array}{l}\text { Control of the correct marking, } \\
\text { including expiration dates and } \\
\text { production dates }\end{array}$ \\
\hline & Physical: & \multicolumn{2}{|c|}{ The stage does not bring physical danger in the presence of PPA } & \\
\hline \multirow{2}{*}{ Storage } & $\begin{array}{l}\text { Chemical: } \\
\text { - toxins produced by moulds; } \\
\text { - products of oxidation and } \\
\text { decomposition of fat and } \\
\text { protein }\end{array}$ & $\begin{array}{l}\text { Toxins produced by mould, } \\
\text { products of oxidation and } \\
\text { decomposition of fat and } \\
\text { protein can lead to severe } \\
\text { poisoning of consumers }\end{array}$ & $\begin{array}{l}\text { Yes } \\
\text { If you do not follow the storage } \\
\text { regime and terms, you may } \\
\text { develop mould in the product and } \\
\text { oxidation and decomposition of } \\
\text { fat and protein }\end{array}$ & \multirow[t]{2}{*}{$\begin{array}{l}\text { Control point. Control of temperature } \\
\text { and shelf life within the production } \\
\text { program of preliminary measures }\end{array}$} \\
\hline & Physical: & \multicolumn{2}{|c|}{ The stage does not bring physical danger in the presence of PPA } & \\
\hline
\end{tabular}

Table 4: Critical control points on the production line of kefir from goat's milk

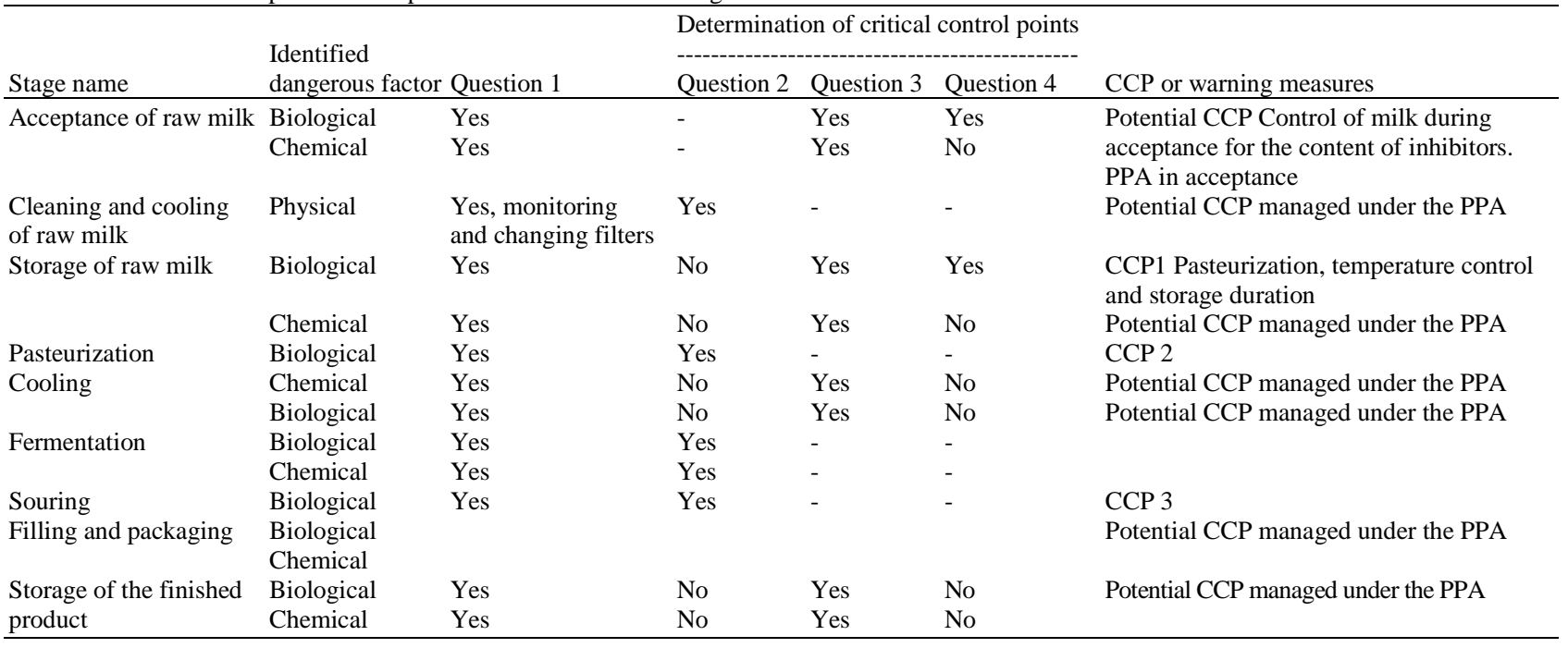

The results of the analysis showed that the sanitary condition of the enterprise is satisfactory, the raw material used for the production of kefir from goat's milk is subject to multiple controls, meets the requirements of standards and, therefore, does not pose a threat to human life and health. During the work of the enterprise of dairy products "Breeding farm "Zerenda" LLP, there were no complaints from consumers, the competent authorities did not register any cases of production of substandard products.

For a more detailed analysis of all possible threats to the production of substandard products, we turned to the statistical data of the enterprise "Breeding farm "Zerenda "LLP, as well as to the documents regulating the quality and safety of the product.
The identified potential hazards and precautionary measures on the production line - kefir from goat's milk are presented in Table 3.

Further, "Decision tree" method was used to determine critical control points, which allowed for a systematic approach to determining the $\mathrm{CCP}$ and can also serve as the main one for developing a documented procedure for selecting the CCP (Fig. 2).

The figure shows that critical points or stages are intended to reduce or eliminate a potentially dangerous factor, as well as stages at which the identified threat may exceed acceptable levels. However, subsequent steps do not eliminate or reduce this dangerous factor to an acceptable level. Determination of the critical control 
points identified during the analysis, we conducted the entire production line of kefir from goat's milk and for each potentially dangerous factor separately.

The definition of critical control points for the technological line for the production of kefir from goat's milk is presented in Table 4.

For the final decision on the degree of criticality of a particular stage of the technological process, we took into account the program of preliminary measures. The implementation of the "Decision Tree" method for the stages of raw milk storage, pasteurization and fermentation leads to the conclusion that these stages are critical control points in relation to the identified preliminary threats to the safety of the dairy product - kefir from goat's milk.

Thus, we have experimentally found that the critical control points for this production process are at the stages: Storage of raw milk, pasteurization, fermentation. All other potential control points are managed within the framework of the preliminary activities program (Table 4 ).

When creating a safety management system for the production of any fermented milk products, including kefir from goat's milk, special attention should be paid to ensuring the safety and quality of the starter cultures used, since the fermentation process often takes place in conditions favorable for the development of undesirable microflora or close to them.

The final stage was the development of the HACCP plan, which reflects preventive measures that eliminate risks or reduce them to an acceptable level and suggests corrective actions (Table 5).

\begin{tabular}{|c|c|c|c|c|c|c|}
\hline $\mathrm{CCP}$ & Dangerous factor & Critical limit & Monitoring procedure & Corrective action & Verification procedure & HACCP record \\
\hline $\begin{array}{l}\text { CCP } 1 . \\
\text { Storage of } \\
\text { raw milk }\end{array}$ & $\begin{array}{l}\text { Accumulation of } \\
\text { enterotoxins as a } \\
\text { result of the } \\
\text { development of } \\
\text { pathogenic microflora } \\
\text { in case of non- } \\
\text { compliance with the } \\
\text { temperature regime } \\
\text { and duration of } \\
\text { storage }\end{array}$ & $\begin{array}{l}\text { Temperature not } \\
\text { higher than } 6^{\circ} \mathrm{C} ; \\
\text { duration-no more } \\
\text { than } 6 \mathrm{~h} \text {; temperature- } \\
\text { no more than } 4{ }^{\circ} \mathrm{C} ; \\
\text { duration- no more } \\
\text { than } 12 \mathrm{~h}\end{array}$ & $\begin{array}{l}\text { Control of milk } \\
\text { temperature and duration } \\
\text { of storage of raw milk } \\
\text { - a master, every } 3 \mathrm{~h}\end{array}$ & $\begin{array}{l}\text { Checking the operation of } \\
\text { the cooling system and } \\
\text { adjusting the temperature. } \\
\text { Informing the Manager to } \\
\text { make a decision about the } \\
\text { future use of milk. If } \\
\text { necessary, according to the } \\
\text { test results, non-conforming } \\
\text { products are rejected. } \\
\text { Identification of the reasons } \\
\text { for the deviation and their } \\
\text { elimination. Conducting } \\
\text { additional training for } \\
\text { employees }\end{array}$ & $\begin{array}{l}\text { Periodic verification and } \\
\text { confirmation of MS accuracy } \\
\text { (once a decade) sampling of } \\
\text { milk from storage tanks } \\
\text { testing for microbiological } \\
\text { indicators. Confirmation of } \\
\text { the correct use or disposal } \\
\text { of non-conforming products. } \\
\text { Staff competency testing at } \\
\text { least once a quarter }\end{array}$ & $\begin{array}{l}\text { Records in the raw milk storage } \\
\text { log and the results of control } \\
\text { tests (Protocol) records of the } \\
\text { MS check. Records of internal } \\
\text { audit results. Records for } \\
\text { deviations and corrective } \\
\text { actions. Records for confirming } \\
\text { the competence of employees }\end{array}$ \\
\hline $\begin{array}{l}\text { CCP } 2 . \\
\text { Pasteurization }\end{array}$ & $\begin{array}{l}\text { Pathogenic microflora } \\
\text { that survived due to } \\
\text { violation of } \\
\text { pasteurization regimes }\end{array}$ & $\begin{array}{l}\text { The temperature } \\
\text { should not be less } \\
\text { than } 90^{\circ} \mathrm{C} \text {. Duration- } \\
\text { at least } 3 \mathrm{~min}\end{array}$ & $\begin{array}{l}\text { Continuous monitoring } \\
\text { of the temperature and } \\
\text { duration of thermograph } \\
\text {-an operator. Check that } \\
\text { the return valve is not up } \\
\text { to pasteurized milk } \\
\text { before each start of the } \\
\text { unit -an operator }\end{array}$ & $\begin{array}{l}\text { Repeated pasteurization. } \\
\text { Isolation of unpasteurized } \\
\text { milk. Informing the Manager } \\
\text { to make a decision on the } \\
\text { wrong product. Identifying } \\
\text { the causes of nonconformity } \\
\text { and eliminating them }\end{array}$ & $\begin{array}{l}\text { Analysis of thermograms. } \\
\text { Microbiological control and } \\
\text { monitoring of phosphatase } \\
\text { activity in pasteurized milk } \\
\text { and finished products. Periodic } \\
\text { verification and confirmation } \\
\text { of MS accuracy (every } 3 \\
\text { months). Checking of log } \\
\text { records of the movement } \\
\text { of pasteurized milk, journal } \\
\text { of control milk from the } \\
\text { pasteurizer, the technical } \\
\text { journal of the work of the } \\
\text { pasteurizer. Testing the } \\
\text { competence of the pasteurization } \\
\text { plant operator at } \\
\text { least once a quarter. } \\
\text { Confirmation of the correct } \\
\text { use or disposal of non- } \\
\text { conforming products and } \\
\text { corrective actions. Internal } \\
\text { audit }\end{array}$ & $\begin{array}{l}\text { Records of temperature control } \\
\text { and pasteurization duration. Log } \\
\text { records of the monitoring of } \\
\text { pasteurized milk. Test reports of } \\
\text { finished products. Record of } \\
\text { MS verification and } \\
\text { confirmation of their accuracy. } \\
\text { Entries in the pasteurized milk } \\
\text { movement log. Record for } \\
\text { validation of competence of the } \\
\text { operator of the pasteurizing } \\
\text { plant. Records for deviations } \\
\text { and corrective actions. Records } \\
\text { of the results of internal audits }\end{array}$ \\
\hline $\begin{array}{l}\text { CCP } 3 . \\
\text { Fermentation }\end{array}$ & $\begin{array}{l}\text { Development of } \\
\text { pathogenic microflora } \\
\text { and accumulation of } \\
\text { enterotoxins as a result } \\
\text { of non-compliance with } \\
\text { fermentation regimes }\end{array}$ & $\begin{array}{l}\text { The temperature is not } \\
\text { more than } 22^{\circ} \mathrm{C} \text {. The } \\
\text { acidity of the clot at the } \\
\text { end of fermentation is } \\
\text { not less than } 85^{\circ} \mathrm{T} \\
\text { (pH 4.65-4.5) }\end{array}$ & $\begin{array}{l}\text { Fermentation temperature } \\
\text { control - a fermentation } \\
\text { operator, every } 3 \mathrm{~h} . \mathrm{pH} \\
\text { control - a fermentation } \\
\text { operator, every } 4 \mathrm{~h} \text {. } \\
\text { Temperature control of } \\
\text { the heating/cooling } \\
\text { agent (water) - a } \\
\text { fermentation operator, } \\
\text { each production }\end{array}$ & $\begin{array}{l}\text { Informing the Manager to } \\
\text { make a decision about } \\
\text { further actions. Product } \\
\text { testing, rejection, isolation } \\
\text { and disposal if necessary. } \\
\text { Identifying the causes of } \\
\text { nonconformity and } \\
\text { eliminating them. } \\
\text { Additional staff training }\end{array}$ & $\begin{array}{l}\text { Control of titrated acidity at } \\
\text { the end of fermentation. } \\
\text { Periodic verification and } \\
\text { confirmation of MS accuracy } \\
\text { (every } 3 \text { months).). } \\
\text { Microbiological control of each } \\
\text { batch of fermented mixture. } \\
\text { Microbiological control of } \\
\text { finished products (once a } \\
\text { decade). Checking records in } \\
\text { the process control log. } \\
\text { Confirmation of the correct use } \\
\text { or disposal of non-conforming } \\
\text { products and corrective actions. } \\
\text { Conducting internal audits. } \\
\text { Testing the competence of } \\
\text { employees of the Fermentation } \\
\text { department and laboratory, at } \\
\text { least once every six months }\end{array}$ & $\begin{array}{l}\text { Record of MS verification } \\
\text { and confirmation of their } \\
\text { accuracy. Recording the } \\
\text { temperature and acidity of the } \\
\text { mixture. Entries in the journal of } \\
\text { microbiological control of the } \\
\text { fermented mixture, test reports } \\
\text { of the fermented mixture and } \\
\text { finished products. Records } \\
\text { based on the results of internal } \\
\text { audits. Records confirming the } \\
\text { competence of employees of the } \\
\text { Fermentation department and } \\
\text { laboratory }\end{array}$ \\
\hline
\end{tabular}




\section{Conclusion}

In accordance with the requirements of ST RK ISO 22000-2006 RK 1179-2003 LLP "Breeding farm" Zerenda" of Akmola region on the technological line for the production of yogurt from goat's milk, comprising the following stages: Acceptance of raw milk, the acceptance of a fungal yeast, purification of raw milk, cooling and storing raw milk, separation, normalization, purification, homogenization, pasteurization, cooling, fermentation products, fermentation, mixing and cooling, maturation, bottling, packaging, labeling and identified threat of biological, physical, chemical factors; three critical control points have been identified at the stages of raw milk storage, pasteurization and fermentation. Preventive measures have been developed and corrective actions have been proposed for the production process.

The developed HACCP system for the production of products-kefir from goat's milk will allow the company to timely identify adverse conditions and threats arising during the life cycle in order to eliminate and timely prevent the possibility of low-quality products, which will first of all ensure safety for the life and health of the population, competitiveness at the international level, reduce the overall cost of monitoring, which will improve the company's position in the dairy market, increase the net income of the enterprise necessary for its further development.

Currently, the procedure for implementing the HACCP system in "Breeding farm" Zerenda "LLP is being completed.

\section{Acknowledgement}

This study was funded by the Ministry of Education and Science of the Republic of Kazakhstan

\section{Author's Contributions}

Gaukhar Yussupova and Dina Kurmangaliyeva: Conceived and planned the study.

Begjan Kalemshariv and Nadezhda Lantseva: Conducted lab work and drafted the manuscript.

Askar Muratov and Zhadyra Salykbaeva: Did statistical analysis of data.

Gaukhar Yussupova: Revised the manuscript.

\section{Ethics}

This article is original and contains unpublished material. The corresponding author confirms that all of the other authors have read and approved the manuscript and there are no ethical issues involved.

\section{References}

Antonov, A. E., \& Shiryaev, D. S. (2015). HACCP group Dreamteem enterprises. Dairy industry. 6, 45-53.

Aptrakhimov, D. R., \& Rebezov, M. B. (2014). Review of the macaroni market. Modern business space: Current problems and prospects. 2(3), 116-118.

Baryshnikova, N. I., Reznichenko, I. Y., \& Vaiskrobova, E. S. (2017). Development of a safety management system based on the principles of HACCP. Technique and technology of food production. 47(4), 115-12.

Bondareva, E. D. (2010). HACCP-security system. Methods of conformity assessment. 1, 20-22.

Grevtsova, S. A., Kabulova, M. U., \& Genoan, K. R. (2016). Quality Management of products based on HACCP principles. Gorsky State Agrarian University. 9, 199-210.

Klementieva, L. A., \& Lanceva, N. N. (2017). Using the HACCP system in all segments of the food industry. In: The Problems of biology and biotechnology proceedings of the conference of the scientific society of students and postgraduates of the faculty of biology and technology. Novosibirsk state agrarian University.

Kantere, V. M., Matison, V. A., \& Sazonov, Y. S. (2008). Integrated management systems in food industry: monograph institute of quality safety and environmental management of food enterprises; Moscow State University of food production. Moscow, 522.

Mortimore, S. W. (2014). HACCP. Practical guidelines. St. Petersburg.: Profession publishing house.

Prokoshenkova, M. A., \& Lantseva, N. N. (2019). Algorithm for the implementation of HACCP on the projected line of hard cheeses in LLC "Milk Alphabet". Problems of Biology and Biotechnology: Sat. Proceedings of the Conference of the Scientific Society of Students and Postgraduates of the Faculty of Biology and Technology. Novosib. state agrarian. un-t - Novosibirsk: Information Center of the National State Agrarian University "Golden Ear", pp: 93-95.

Smirnova, N. A., Smirnov, A. A., \& Bedrina, V. V. (2015). Ways to improve the quality and safety of food products. Actual problems of development of modern science and education: SB. nauch. tr. based on the materials of the International scientific and practical conference. 
Tolstova, E. G. (2013). Control of raw materials as a necessary condition for ensuring the safety of finished products. Vestnik NGIEI. 8(27), 99-103.

Yussupova, G. T., Kurmangalieva, D. B., \& Lantseva, N. N. (2019). Problems and prospects for the implementation of the HACCP system. Bulletin of ATU. 3, 14.
Vasileva, I. V. (2013). Development of the HACCP plan for ensuring the safety of kvass production. Technique and technology of food production. 2. 1

Zamyamina, O. V. (2006). HACCP principles. Food Safety and Medical Equipment. Standards and quality. 